\title{
Tree biomass and carbon stock assessment of two forest areas of Assam in North East India
}

\author{
Maina Borah'1, H. P. Deka Boruah' and Bijoy Neog ${ }^{3}$ \\ ${ }^{1}$ Corresponding author: Department of Botany, Pandu College, Guwahati-781012, Assam, India \\ E-mail:mainaborah85@gmail.com \\ ${ }^{2}$ Department of Biotechnology, CSIR-North-East Institute of Science and Technology, Jorhat-785006, \\ Assam, India \\ ${ }^{3}$ Department of Life Science, Dibrugarh University, Dibrugarh-786004, Assam, India
}

[Received 06.05.2019; Revised 19.06.2019; Accepted 23.06.2019; Published 30.06.2019]

\begin{abstract}
The present study was carried out for assessment of tree above ground biomass and carbon stock of two forest areas of Assam viz. Poba Reserve Forest (PRF) and Nambor-Doigrung Wildlife Sanctuary (NDWS). Data were collected from ten random plots of 0.1 ha for both forests. In each plot, all tree species having diameter at breast height (dbh) more than or equal to $10 \mathrm{~cm}$ were identified and their height as well as dbh were measured. Above ground biomass (AGB) was estimated by using allometric equations. The Diversity Indices were also calculated for each study site. AGB and above ground carbon (AGC) values were found to be highly variable across all plots, with the average values of $110.07 \mathrm{Mg} \mathrm{ha}^{-1}$ and $55.03 \mathrm{Mg} \mathrm{C} \mathrm{ha}^{-1}$, respectively for PRF and $91.04 \mathrm{Mg} \mathrm{ha}^{-1}$ and $45.52 \mathrm{Mg} \mathrm{C}^{-1}$ respectively for NDWS. There were 2396 stems ha $^{-1}$, belonging to 63 tropical species, 48 genera and 27 families in the PRF. In NDWS, there were 1666 stems ha $^{-1}$, belonging to 43 tropical species, 35 genera and 21 families. A positive and significant linear relationship among the tree growth variables was found for both the forests which facilitate insights into the role of biodiversity in maintaining carbon storage. The average soil carbon stock (SOC) in the upper, middle and lower layers was $50.07-73.63 \mathrm{~kg}$ $\mathrm{m}^{-2}, 37.25-66.01 \mathrm{~kg} \mathrm{~m}^{-2}$ and 36.60-57.42 $\mathrm{kg} \mathrm{m}^{-2}$, respectively in PRF and NDWS. However, compared to NDWS, a higher AGB and AGBC were found in PRF due to the presence of old growth matured forest with big and diverse tree species in PRF.
\end{abstract}

Key words: Above ground biomass, Biodiversity, Soil organic carbon, Tree diversity, Carbon stock

\section{INTRODUCTION}

Tree composition and structure of forests provide a vital instrument in assessment of sustainability of the forests, conservation of species and in management of the forest ecosystems. Again, in mitigating the effects of global warming, forests play an important role since it acts as one of the largest carbon pool (Sasaki \& Kim 2009). The carbon stock potentiality of a forest can be determined by estimating its biomass. However, the above ground biomass (AGB) of most of the forests is directly affected by deforestation and forest degradation (Gibbs et al. 2007). Therefore, estimation of AGB is the most important aspect in the study of carbon stock of forest (Ketterings et al. 2001). Among different methods for quantifying AGB of a forest, nondestructive method is more preferable for its cost effectiveness, eco-friendly nature (Chave et al. 2005; Ravindranath \& Ostwald 2008; Kunneke et al. 2014; Seifert \& Seifert 2014; Magalhães, \& Seifert 2015; Picard et al. 2015). 
North East India - a gift of nature is having several different types of forest and is one of the mega biodiversity hot spot. The forests of this region are also not an exception regarding its lost in diversity, diminishing its areas and natural beauty due to anthropogenic activities. Shifting cultivation operation in NE India are most apparent causes of forests disturbances. The problem with shifting cultivation is that plants or ecosystem often do not get time to recover adequately as the human onslaught never stops (Singh 1998). Along with shifting cultivation, over exploitation, encroachment, flood, erosion, urbanization is the major threats for the normal growth and development of forests of this region. Apart from these, information related to nature of forest, $\mathrm{AGB}$ carbon stocks (AGBC) is rather inadequate in these forest habitats. In order to fill up this gap, it is necessary to assess representative forests in respect of characteristics and its role in maintaining the environment. In this study, species diversity, biomass and carbon stocks in two forest areas of Assam, i.e., the PRF and NDWS were assessed.

\section{Study Area}

The study was conducted in Poba Reserve Forest (PRF) and Nambor-Doigrung Wildlife Sanctuary (NDWS) of Assam. PRF is situated in Jonai Subdivision of Dhemaji district, Assam. The Reserved Forest (RF) was created in the year 1924 and covers an area of 10,221 hectares. The forest receives annual rainfall of $3600 \mathrm{~mm}$ to $4000 \mathrm{~mm}$. The highest temperature recorded is $35^{\circ} \mathrm{C}$ in summer and lowest $7^{\circ} \mathrm{C}$ in winter. It is surrounded by Daying Ering Wildlife Sanctuary, NH-52 and foot-hills of Arunachal Pradesh in the North, Dibru-Saikhowa National Park and the Siang, Dibang and Lohit rivers in the East, Laly River in the South, and a few villages to the West. Boruah et al. (2003) from Assam Remote Sensing Application Centre, Guwahati on the basis of Satellite Remote Sensing Technique classified the vegetation cover of the RF into five types i.e. moist mixed semievergreen forest, moist mixed deciduous forest, degraded forest, tall grasses and small grasses. The NDWS occupies an area of 9,715 ha. The NDWS extends up to a foothill area of Karbi Anglong district is located in Golaghat district of Upper Assam. The mean annual temperature varies from $6^{\circ} \mathrm{C}$ to $36^{\circ} \mathrm{C}$ and rainfall from $2000 \mathrm{~mm}$ to $2300 \mathrm{~mm}$. The plains are the floodplains of the Dhansiri River. The forest type is Tropical Semi-evergreen rainforest with of evergreen and marsh forest. The middle storey is dense and the undergrowth includes bamboo, other shrubs, and some deciduous tree species like Tetrameles nudiflora can be seen in the range. The geographical location of the two reserves has been presented in Table 1 .

Table 1. Location (central coordinates) of the studied forests in Assam

\begin{tabular}{|l|c|c|}
\hline \multicolumn{1}{|c|}{ Study Site name } & Latitude & Longitude \\
\hline Poba Reserve Forest (PRF) & $27^{\circ} 50^{\prime} \mathrm{N}$ & $95^{\circ} 17^{\prime} \mathrm{E}$ \\
\hline $\begin{array}{l}\text { Nambor-Doigrung Wildlife } \\
\text { Sanctuary (NDWS) }\end{array}$ & $26^{\circ} 25^{\prime} \mathrm{N}$ & $93^{\circ} 43^{\prime} \mathrm{E}$ \\
\hline
\end{tabular}

\section{METHODOLOGY}

For the present study a non-destructive sampling method was adopted to estimate above ground biomass (AGB) and carbon stocks of tree species. In each forest site, a plot of 250 $\mathrm{m} \times 250 \mathrm{~m}$ size was taken. Four sample plots, each of $31.6 \mathrm{~m} \times 31.6 \mathrm{~m}(0.1 \mathrm{ha})$ size were taken in the four corner of the plot according to the field manual for "vegetation carbon pool" assessment of India (Dadhwal et al. 2009). In each sample plot, girths of all the trees (e" 10 $\mathrm{cm} \mathrm{DBH}$ ) were measured at $1.37 \mathrm{~m}$ height from the ground by using metal measuring tape. 
Vegetation composition was assessed by analysing the Frequency, Density, Abundance and Importance Value Index (IVI) according to Curtis and McIntosh (1951) and Mishra (1968). Species richness (at species, genera and family levels), stem density, Fisher's alpha and basal area $\mathrm{m}^{2} \mathrm{ha}^{-1}$ were assessed for each of the ten 0.1 ha plots. Fisher's alpha (a measure of diversity) which is fairly independent of plot size was used to assess species diversity (Condit et al. 1998; Fisher et al. 1943). The basal area of all trees in the sample plots were calculated using the formula:

$$
\mathrm{BA}=\left(\ddot{\mathrm{e}} \mathrm{D}^{2}\right) / 4
$$

where, $\mathrm{BA}=$ Basal area $\left(\mathrm{m}^{2}\right), \mathrm{D}=$ Diameter at breast height $(\mathrm{cm})$ and $\ddot{\mathrm{e}}=$ pie $(3.142)$. The total BA for each plot was obtained by adding all trees BA in the plot. Shannon and Simpson diversity indices (Shannon \& Weaver 1963; Simpson 1949) were calculated to determine the species abundance relationships in plant communities. Beta diversity (â) was calculated by Whittaker (1972) to designate the degree of species change along a given habitat as such it is a measure of between area diversity. Evenness was calculated by as given by Pielou (1966).

The volume of each tree was calculated by using the Newton's formula (Husch et al. 2003). Species-specific wood density was obtained from the global wood density database (Chave et al. 2009). Besides, for species that lacked species-level wood density values, genus-level averages were used. The AGB was estimated using the allometric model proposed by Chave et al. (2005) for moist forest stands as the mean annual precipitation of the selected sites is between 1500 and $3000 \mathrm{~mm}$. The AGBC stock was calculated that by assuming that the carbon mass fraction of the dry wood is $50 \%$ of the total AGB (Ravindranath et al. 1997).

The collected plant specimens were identified with the help of floras, books and literature including Kanjilal et al. (1934 - 1940); Barooah and Ahmed (2014); Balakrishnan (1983); Goswami and Barua (1996) and taxonomic keys available at http://www.efloras.org. For the updated nomenclature and family delimitation http://www.theplantlist.org/ was mostly consulted. Voucher specimens were deposited in herbarium of the CSIR NEIST, Jorhat, Assam.

\section{Statistical analysis}

Pearson Correlation Coefficient was used to examine the relationship among the growth variables. Student t-test was performed to determine significant difference between soil parameters at $\mathrm{p}<0.05$. All analyses were performed with SPSS 16.0.

\section{RESULTS}

The tree density of the present study is $138.83-205.66$ trees ha ${ }^{-1}$. Basal area ranged from $19.69-46.62 \mathrm{~m}^{2} \mathrm{ha}^{-1}$. Tectona grandis was the dominant species in the PRF, with the IVI value 8.35. The Co-dominant species are Vatica lanceifolia and Cinnamomum bejolghota with IVI value 6.09 and 6.0 respectively. A total of 63 species are recorded from the PRF. $100 \%$ frequency was reported by Tectona grandis, Lagerstroemia speciosa, Canarium bengalense, Tetrameles nudiflora and Alstonia scholaris. The minimum IVI value (3.51) was reported for Mesua ferrea. $75 \%$ frequency was observed by the twenty-three species. The A/F ratio was in the range from 0.03 to 0.10 . Density of 205.66 trees $\mathrm{ha}^{-1}$ was recorded in the PRF. 
22 Tree biomass and carbon stock assessment in Assam forests

Table 2. Distribution analysis of tree species in Poba Reserve Forest (PRF).

\begin{tabular}{|c|c|c|c|c|c|c|c|}
\hline Family & Botanical name & Local name & D & $\mathbf{F}$ & A & $\mathbf{A} / \mathbf{F}$ & IVI \\
\hline \multirow[t]{6}{*}{ Lauraceae } & Litsea monopetala (Roxb.) Pers. & Sualu & 2.58 & 83 & 3.10 & 0.04 & 4.18 \\
\hline & Phoebe cooperiana P.C.Kanjilal \& Das & Mekahi & 3.17 & 92 & 3.45 & 0.04 & 4.98 \\
\hline & Phoebe goalparensis Hutch. & Bonsum & 3.33 & 75 & 4.44 & 0.06 & 4.98 \\
\hline & Cinnamomum glanduliferum (Wall.) Meisn. & Gansoroi & 3.50 & 67 & 5.25 & 0.08 & 5.05 \\
\hline & Cinnamomum bejolghota (Buch.-Ham.) Sweet & Paihunda & 3.33 & 83 & 4.00 & 0.05 & 6.01 \\
\hline & Beilschmiedia assamica Meisn. & Amchoi & 2.92 & 75 & 3.89 & 0.05 & 4.85 \\
\hline \multirow[t]{6}{*}{ Lamiaceae } & Alseodaphne owdenii R.Parker & Jatisundi & 2.92 & 67 & 4.38 & 0.07 & 4.65 \\
\hline & Tectona grandis L.f. & Shagun, Teak & 7.50 & 100 & 7.50 & 0.08 & 8.35 \\
\hline & Gmelina arborea Roxb. & Gomari & 2.67 & 75 & 3.56 & 0.05 & 5.55 \\
\hline & Callicarpa arborea Roxb. & Bonmola & 2.92 & 83 & 3.50 & 0.04 & 4.78 \\
\hline & Premna bengalensis C.B.Clarke & Pakhirhar & 3.50 & 58 & 6.00 & 0.10 & 5.76 \\
\hline & Vitex peduncularis Wall. ex Schauer & Akhoi & 3.08 & 83 & 3.70 & 0.04 & 5.21 \\
\hline \multirow[t]{6}{*}{ Moraceae } & Ficus hispida L.f. & Dimoru & 3.50 & 75 & 4.67 & 0.06 & 4.44 \\
\hline & Artocarpus chama Buch.-Ham. & Samgos & 2.42 & 75 & 3.22 & 0.04 & 4.89 \\
\hline & Artocarpus lacucha Buch.-Ham. & Bohot & 2.92 & 75 & 3.89 & 0.05 & 4.61 \\
\hline & Artocarpus chaplasha Roxb. & Sam & 2.83 & 75 & 3.78 & 0.05 & 4.43 \\
\hline & Morus macroura Miq. & Bola & 2.83 & 67 & 4.25 & 0.06 & 4.58 \\
\hline & Ficus nervosa B.Heyne ex Roth & Khari pati & 2.67 & 83 & 3.20 & 0.04 & 4.24 \\
\hline \multirow[t]{8}{*}{ Malvaceae } & Bombax ceiba L. & Simolu & 4.42 & 75 & 5.89 & 0.08 & 5.53 \\
\hline & Pterospermum acerifolium (L.) Willd. & Moragos & 2.83 & 67 & 4.25 & 0.06 & 5.14 \\
\hline & Kydia calycina Roxb. & Pichola & 2.75 & 58 & 4.71 & 0.08 & 4.12 \\
\hline & Pterospermum lanceifolium Roxb. & - & 3.25 & 75 & 4.33 & 0.06 & 4.50 \\
\hline & $\begin{array}{l}\text { Sloanea sterculiacea var. assamica (Benth.) } \\
\text { Coode }\end{array}$ & Joba hingori & 2.75 & 67 & 4.13 & 0.06 & 4.21 \\
\hline & Pterygota alata (Roxb.) R.Br. & Pahari & 3.42 & 75 & 4.56 & 0.06 & 4.86 \\
\hline & Sterculia villosa Roxb. & Udal & 2.83 & 75 & 3.78 & 0.05 & 4.59 \\
\hline & Mansonia dipikae Purkayastha & Badam & 3.67 & 75 & 4.89 & 0.07 & 4.59 \\
\hline \multirow[t]{4}{*}{ Combretaceae } & $\begin{array}{l}\text { Terminalia myriocarpa Van Heurck \& } \\
\text { Müll.Arg }\end{array}$ & Hoolokh & 2.50 & 83 & 3.00 & 0.04 & 4.54 \\
\hline & $\begin{array}{l}\text { Terminalia arjuna (Roxb. ex DC.) Wight \& } \\
\text { Arn. }\end{array}$ & Arjun & 2.17 & 75 & 2.89 & 0.04 & 4.70 \\
\hline & Terminalia chebula Retz. & Hilika & 3.00 & 83 & 3.60 & 0.04 & 5.52 \\
\hline & Terminalia bellirica (Gaertn.) Roxb. & Bauri & 2.83 & 75 & 3.78 & 0.05 & 4.31 \\
\hline \multirow[t]{3}{*}{ Magnoliaceae } & $\begin{array}{l}\text { Magnolia hodgsonii (Hook.f. \& Thomson) } \\
\text { H.Keng }\end{array}$ & Barhamthuri & 4.08 & 67 & 6.13 & 0.09 & 4.71 \\
\hline & \multicolumn{2}{|l|}{ Magnolia doltsopa (Buch.-Ham. ex DC.) Figlar } & 2.75 & 75 & 3.67 & 0.05 & 5.21 \\
\hline & Magnolia griffithii Hook.f. \& Thomson & Gahari sopa & 3.67 & 75 & 4.89 & 0.07 & 4.64 \\
\hline \multirow[t]{3}{*}{ Meliaceae } & Aglaia spectabilis (Miq.) S.S.Jain \& S.Bennet & Amari & 2.42 & 83 & 2.90 & 0.03 & 4.34 \\
\hline & Toona ciliate M.Roem. & Poma & 3.42 & 67 & 5.13 & 0.08 & 5.47 \\
\hline & \multicolumn{2}{|l|}{ Dysoxylum gotadhora (Buch.-Ham.) Mabb. } & 2.67 & 75 & 3.56 & 0.05 & 5.60 \\
\hline \multirow[t]{2}{*}{ Phyllanthaceae } & Bischofia javanica Blume & Urium & 3.83 & 83 & 4.60 & 0.06 & 5.03 \\
\hline & Antidesma acidum Retz. & Abutenga & 2.50 & 83 & 3.00 & 0.04 & 4.38 \\
\hline \multirow[t]{7}{*}{ Leguminosae } & Dalbergia sissoo DC. & SisSOO & 2.67 & 75 & 3.56 & 0.05 & 4.18 \\
\hline & Dalbergia assamica Benth. & Sissoo & 2.75 & 75 & 3.67 & 0.05 & 4.25 \\
\hline & Albizia procera (Roxb.) Benth. & Koroi & 3.00 & 67 & 4.50 & 0.07 & 4.88 \\
\hline & Albizia lebbeck (L.) Benth. & Siris & 2.67 & 58 & 4.57 & 0.08 & 4.46 \\
\hline & Albizia lucida Benth. & Potka Siris & 3.00 & 67 & 4.50 & 0.07 & 4.35 \\
\hline & Erythrina suberosa Roxb. & Modar & 2.92 & 83 & 3.50 & 0.04 & 4.19 \\
\hline & Bauhinia purpurea L. & $O g$-vok & 2.75 & 92 & 3.00 & 0.03 & 3.95 \\
\hline \multirow[t]{3}{*}{ Lythraceae } & Duabanga grandiflora (DC.) Walp. & Bondorphulla & 2.92 & 75 & 3.89 & 0.05 & 4.78 \\
\hline & Lagerstroemia speciosa (L.) Pers. & Ajar & 4.58 & 100 & 4.58 & 0.05 & 5.85 \\
\hline & Lagerstroemia parviflora Roxb. & Ajar & 2.92 & 92 & 3.18 & 0.03 & 5.08 \\
\hline \multirow[t]{2}{*}{ Euphorbiaceae } & Mallotus repandus (Willd.) Müll.Arg. & Bhelko & 3.00 & 83 & 3.60 & 0.04 & 4.53 \\
\hline & Mallotus philippensis (Lam.) Müll.Arg. & Red Kamala & 2.33 & 92 & 2.55 & 0.03 & 4.56 \\
\hline Rubiaceae & Pavetta indica L. & - & 4.33 & 75 & 5.78 & 0.08 & 5.26 \\
\hline Actinidiaceae & Saurauia roxburghii Wall. & Bon posola & 3.67 & 83 & 4.40 & 0.05 & 3.85 \\
\hline Altingiaceae & Altingia excelsa Noronha & Jutuli & 3.67 & 92 & 4.00 & 0.04 & 3.95 \\
\hline Burseraceae & Canarium bengalense Roxb. & Dhuna & 4.42 & 100 & 4.42 & 0.04 & 5.03 \\
\hline Bignoniaceae & Stereospermum chelonoides (L.f.) DC. & Paroli & 3.58 & 92 & 3.91 & 0.04 & 4.11 \\
\hline Calophyllaceae & Mesua ferrea $\mathrm{L}$. & Nahor & 2.67 & 75 & 3.56 & 0.05 & 3.51 \\
\hline Dilleniaceae & Dillenia indica $\mathrm{L}$. & Ou tenga & 3.50 & 83 & 4.20 & 0.05 & 4.04 \\
\hline Tetramelaceae & Tetrameles nudiflora $\mathrm{R} . \mathrm{Br}$. & Bhelu & 7.08 & 100 & 7.08 & 0.07 & 5.83 \\
\hline Apocynaceae & Alstonia scholaris (L.) R. Br. & Sativana & 2.75 & 100 & 2.75 & 0.03 & 4.47 \\
\hline Dipterocarpaceae & Vatica lanceifolia (Roxb.) Blume & Morhal & 4.50 & 92 & 4.91 & 0.05 & 6.10 \\
\hline Fagaceae & Castanopsis indica (Roxb. ex Lindl.) A.DC. & Hingori & 2.75 & 92 & 3.00 & 0.03 & 4.92 \\
\hline Rutaceae & Evodia meliifolia (Hance ex Walp.) Benth. & Maiphak & 4.42 & 92 & 4.82 & 0.05 & 5.78 \\
\hline
\end{tabular}

The maximum IVI (12.04) was for the Bombax ceiba, Gmelina arborea and Lagerstroemia speciosa has the IVI value of 10.62 and 9.85 respectively. 100\% frequency 
was recorded for the Bombax ceiba, Gmelina arborea and Lagerstroemia speciosa. 83 $\%$ frequency was observed for the sixteen species. A Density of 138.83 trees ha ${ }^{-1}$ was recorded in the NDWS. The $\mathrm{A} / \mathrm{F}$ ratio was in the range from 0.03 to 0.09 . The minimum IVI Value (4.78) was recorded for the Pterygota alata (Table 3).

Table 3. Distribution analysis of tree species in Nambor Doigrung Wildlife Sanctuary

\begin{tabular}{|c|c|c|c|c|c|c|c|}
\hline Family & Botanical name & Local name & D & $\mathbf{F}$ & $\mathbf{A}$ & $\mathbf{A} /$ & IV \\
\hline \multirow[t]{7}{*}{ Leguminosae } & Albizia lebbeck (L.) Benth. & Siris & 2.17 & 92 & 2.36 & 0.0 & 6.2 \\
\hline & Albizia procera (Roxb.) Benth. & Koroi & 3.92 & 83 & 4.70 & 0.0 & 7.7 \\
\hline & Albizia odoratissima (L.f.) Benth. & Siris & 4.58 & 92 & 5.00 & 0.0 & 6.5 \\
\hline & Bauhinia purpurea L. & $O g-y o k$ & 2.58 & 92 & 2.82 & 0.0 & 7.7 \\
\hline & Butea monosperma (Lam.) Taub. & Palash & 3.67 & 92 & 4.00 & 0.0 & 8.4 \\
\hline & Dalbergia sissoo DC. & Sissoo & 4.17 & 67 & 6.25 & 0.0 & 9.3 \\
\hline & Cassia fistula $\mathrm{L}$. & Shunaru & 2.42 & 75 & 3.22 & 0.0 & 5.5 \\
\hline \multirow[t]{4}{*}{ Malvaceae } & Pterospermum acerifolium (L.) Willd. & Moragos & 3.00 & 92 & 3.27 & 0.0 & 6.1 \\
\hline & Pterygota alata (Roxb.) R.Br. & Pahari & 1.67 & 67 & 2.50 & 0.0 & 4.7 \\
\hline & Sterculia villosa Roxb. & Udal & 2.92 & 92 & 3.18 & 0.0 & 5.5 \\
\hline & Bombax ceiba $\mathrm{L}$. & Simolu & 7.75 & 10 & 0.00 & 0.0 & 12. \\
\hline \multirow{3}{*}{ Clusiaceae } & Garcinia cowa Roxb. ex DC. & Kau thekera & 4.33 & 92 & 4.73 & 0.0 & 7.1 \\
\hline & Garcinia morella (Gaertn.) Desr. & Kuiithekera & 2.33 & 83 & 2.80 & 0.0 & 5.3 \\
\hline & Garcinia pedunculata Roxb. ex Buch.-Ham. & Bar thekera & 3.58 & 75 & 4.78 & 0.0 & 5.4 \\
\hline \multirow[t]{3}{*}{ Moraceae } & Streblus asper Lour. & - & 4.42 & 83 & 5.30 & 0.0 & 8.5 \\
\hline & Ficus semicordata Buch.Ham. ex Sm. & Tokuk asing & 2.75 & 92 & 3.00 & 0.0 & 6.8 \\
\hline & Artocarpus heterophyllus Lam. & Kothal & 2.33 & 75 & 3.11 & 0.0 & 7.2 \\
\hline \multirow[t]{3}{*}{ Lauraceae } & Phoebe cooperiana P.C.Kanjilal \& Das & Mekahi & 2.67 & 67 & 4.00 & 0.0 & 8.0 \\
\hline & Litsea monopetala (Roxb.) Pers. & Soalu & 3.50 & 83 & 4.20 & 0.0 & 8.3 \\
\hline & Phoebe goalparensis Hutch. & Bonsum & 2.83 & 58 & 4.86 & 0.0 & 5.0 \\
\hline \multirow[t]{2}{*}{ Lamiaceae } & Gmelina arborea Roxb. & Gomari & 4.42 & 10 & 4.42 & 0.0 & 0.6 \\
\hline & Callicarpa arborea Roxb. & Bonmola & 3.58 & 92 & 3.91 & 0.0 & 9.6 \\
\hline \multirow[t]{2}{*}{ Apocynaceae } & Plumeria alba $\mathrm{L}$. & Champa & 4.33 & 92 & 4.73 & 0.0 & 6.1 \\
\hline & Alstonia scholaris (L.) R. Br. & Sativana & 4.42 & 92 & 4.82 & 0.0 & 7.4 \\
\hline \multirow[t]{2}{*}{ Lythraceae } & Duabanga grandiflora (DC.) Walp. & Bondorphulla & 2.25 & 83 & 2.70 & 0.0 & 5.5 \\
\hline & Lagerstroemia speciosa (L.) Pers. & Ajar & 4.33 & 10 & 4.33 & 0.0 & 9.8 \\
\hline \multirow[t]{2}{*}{ Magnoliaceae } & Magnolia globosa Hook.f. \& Thomson & - & 1.75 & 75 & 2.33 & 0.0 & 5.9 \\
\hline & Magnolia hodgsonii (Hook.f. \& Thomson) H.Keng & Barhamthuri & 2.08 & 83 & 2.50 & 0.0 & 5.6 \\
\hline \multirow[t]{2}{*}{ Phyllanthaceae } & Baccaurea ramiflora Lour. & Leteku & 2.08 & 83 & 2.50 & 0.0 & 5.8 \\
\hline & Bischofia javanica Blume & Urium & 4.42 & 83 & 5.30 & 0.0 & 8.4 \\
\hline \multirow[t]{2}{*}{ Meliaceae } & Azadirachta indica A.Juss. & Neem & 1.67 & 75 & 2.22 & 0.0 & 5.1 \\
\hline & Toona ciliata M.Roem. & Poma Jatipoma & 2.42 & 75 & 3.22 & 0.0 & 4.9 \\
\hline \multirow[t]{2}{*}{ Euphorbiaceae } & Mallotus nudiflorus (L.) Kulju \& Welzen & Bhelko & 3.58 & 83 & 4.30 & 0.0 & 7.3 \\
\hline & Mallotus philippensis (Lam.) Müll.Arg. & Red Kamala & 3.67 & 83 & 4.40 & 0.0 & 5.9 \\
\hline \multirow[t]{2}{*}{ Rhamnaceae } & Ziziphus jujuba Mill. & Bogori & 3.08 & 92 & 3.36 & 0.0 & 5.7 \\
\hline & Ziziphus rugosa Lam. & Bon bogori & 3.92 & 75 & 5.22 & 0.0 & 5.5 \\
\hline Altingiaceae & Altingia excelsa Noronha & Jutuli & 3.00 & 83 & 3.60 & 0.0 & 5.1 \\
\hline Bixaceae & Bixa orellana $\mathrm{L}$. & Jolandhar & 2.92 & 92 & 3.18 & 0.0 & 5.6 \\
\hline Dilleniaceae & Dillenia indica $\mathrm{L}$. & Ou-tenga & 2.50 & 83 & 3.00 & 0.0 & 5.7 \\
\hline Moringaceae & Moringa oleifera Lam. & Sajana & 2.33 & 83 & 2.80 & 0.0 & 4.9 \\
\hline Sapotaceae & Mimusops elengi $\mathrm{L}$. & Bakul & 2.75 & 83 & 3.30 & 0.0 & 5.8 \\
\hline Sapindaceae & Sapindus mukorossi Gaertn. & Reetha & 2.33 & 83 & 2.80 & 0.0 & 7.7 \\
\hline Tetramelaceae & Tetrameles nudiflora $\mathrm{R}$. Br. & Bhelu & 3.42 & 83 & 4.10 & 0.0 & 8.4 \\
\hline
\end{tabular}

$\alpha$-diversity (Species Richness) was the maximum 63 for PRF. NDWS has reported 43 as its $\alpha$-diversity. Beta Diversity 2.5 was recorded for NDWS. The highest Concentration of Dominance $(\mathrm{Cd})(0.312)$ was recorded for PRF while NDWS showed 0.243 Concentration of Dominance (Cd). The highest H' (4.12) was recorded in the PRF while the lowest H' (3.7) was recorded in NDWS. The maximum value of Evenness $(\mathrm{J})(0.73)$ was recorded in the PRF while the minimum (0.71) was recorded in the NDWS (Table 4).

Table 4. Diversity index of trees at PRF and NDWS

\begin{tabular}{|c|c|c|}
\hline Indices & $\begin{array}{l}\text { Poba Reserve } \\
\text { Forest }\end{array}$ & $\begin{array}{l}\text { Nambor Doigrung } \\
\text { Wildlife Sanctuary }\end{array}$ \\
\hline Richness $(\alpha)$ & 63 & 43 \\
\hline Diversity $(\beta)$ & 2.33 & 2.5 \\
\hline Dominance $(\mathrm{Cd})$ & 0.312 & 0.243 \\
\hline Shannon(H') & 4.12 & 3.7 \\
\hline
\end{tabular}


The AGB of the present study ranged from $91.04 \mathrm{Mg} \mathrm{ha}^{-1}$ to $110.07 \mathrm{Mg} \mathrm{ha}^{-1}$. Similarly, the values of AGBC stocks in this study ranged from $45.52 \mathrm{Mg} \mathrm{ha}^{-1}$ to $55.03 \mathrm{Mg} \mathrm{ha}^{-1}$. Overall compared to the NDWS, AGB and AGBC stocks were recorded less than PRF. This result of higher AGB and AGBC stocks in PRF also substantiates the positive relationship of basal area with AGB to that of matured large tree composition and old growth managed reserve forest (Table 5).

Table 5. Above ground biomass and carbon stocks

\begin{tabular}{|l|c|c|}
\hline \multicolumn{1}{|c|}{ Forest } & $\begin{array}{c}\text { Aboveground } \\
\text { biomass } \\
\left(\mathbf{M g ~ h a}^{-1}\right)\end{array}$ & $\begin{array}{c}\text { Aboveground } \\
\text { biomass carbon } \\
\left(\mathbf{M g ~ h a}^{-1}\right)\end{array}$ \\
\hline Poba Reserve Forest & 110.07 & 55.03 \\
\hline $\begin{array}{l}\text { Nambor-Doigrung Wildlife } \\
\text { Sanctuary }\end{array}$ & $\mathbf{9 1 . 0 4}$ & $\mathbf{4 5 . 5 2}$ \\
\hline
\end{tabular}

In PRF, for height distribution the highest proportion of stems (1436 stems ha $\left.{ }^{-1}\right)$ was recorded in the height class of 6-10 $\mathrm{m}$, followed by the height class of $11-15 \mathrm{~m}$ (714 stems ha$\left.{ }^{1}\right)$ (Figure 1). The lowest proportion of stems $\left(44\right.$ stems ha $\left.^{-1}\right)$ was recorded in the height class of Â $5 \mathrm{~m}$. The majority of the trees (60\%) occupied the lower stratum where they form a close canopy (height between $6-10 \mathrm{~m}$ ). Height class of $11-15 \mathrm{~m}$ occupies $30 \%$ of middle and about 5\% and 4\% occupied the upper stratum (16-20 $\mathrm{m}$ and $21-25 \mathrm{~m}$ respectively) (Figure 1). Similarly, in NDWS highest proportion of trees (1204 stems ha-1) was found in 6-10 m, followed by 11-15 m height class with 355 stems $^{-1} \mathrm{ha}^{-1}$. Also the lowest proportion of stems ( $43 \mathrm{stems} \mathrm{ha}^{-1}$ ) was recorded in the height class of $\hat{\mathrm{A}} 5 \mathrm{~m}$. There was no tree species found in the 21-25 m height class. About $72 \%$ of $6-10 \mathrm{~m}$ class occupied the lower stratum. $11-15 \mathrm{~m}$ height class occupied $21 \%$ of middle stratum. Upper stratum in only occupied by $4 \%$ of $16-20 \mathrm{~m}$ trees (Figure 1 ).
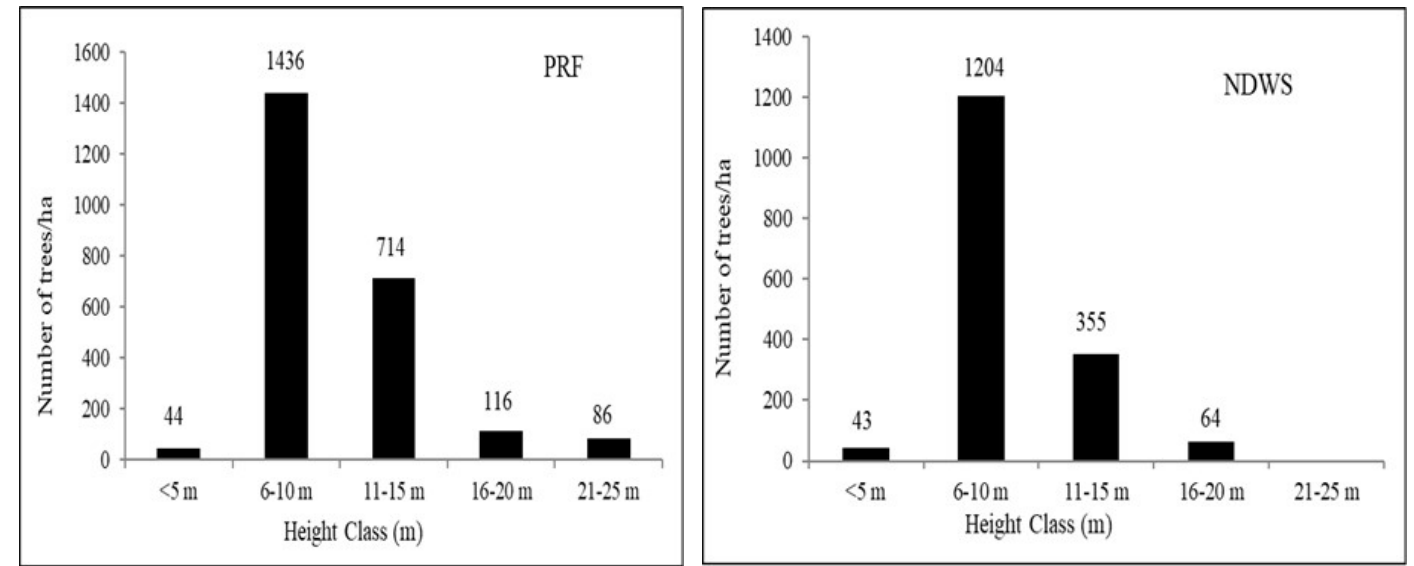

Figure 1. Number of stems ha ${ }^{-1}$ in each of the height classes of PRF and NDWS

There was a positive and significant linear relationship among the tree growth variables both at PRF and NDWS (Table 6). In PRF, the r-values ranged between 0.03 and 0.98 . The highest correlation coefficient was obtained between the height and volume (0.98) followed by basal area and logarithm transformed basal area (0.94). Very weak correlation was observed between DBH and most of the other growth variables. The r-value between the height and basal area and also between heights with logarithm transformed basal area was 
0.03 . Similarly in NDWS, the r-values ranged between 0.21 and 0.97 . The highest correlation coefficient was obtained between the basal area and logarithm transformed basal area (0.97). Very weak correlation was observed between height and other growth variables.

Table 6. Correlation matrix for tree growth variables of PRF and NDWS

\begin{tabular}{|c|c|c|c|c|c|c|}
\hline PRF & DBH(cm) & Height (m) & $\mathbf{B A}\left(\mathrm{m}^{2}\right)$ & $\operatorname{Vol}\left(\mathrm{m}^{3}\right)$ & Ln Ba & Ln Vol \\
\hline DBH(cm) & 1.00 & & & & & \\
\hline Height (m) & 0.21 & 1.00 & & & & \\
\hline BA $\left(\mathrm{m}^{2}\right)$ & 0.23 & 0.03 & 1.00 & & & \\
\hline $\operatorname{Vol}\left(\mathrm{m}^{3}\right)$ & 0.38 & 0.98 & 0.00 & 1.00 & & \\
\hline $\mathrm{Ln} \mathrm{Ba}$ & 0.20 & 0.03 & 0.94 & 0.05 & 1.00 & \\
\hline $\begin{array}{l}\text { Ln Vol } \\
\text { NDWS }\end{array}$ & 0.57 & 0.80 & 0.08 & 0.88 & 0.11 & 1.00 \\
\hline DBH(cm) & 1.00 & & & & & \\
\hline Height (m) & 0.28 & 1.00 & & & & \\
\hline $\mathrm{BA}\left(\mathbf{m}^{2}\right)$ & 0.21 & 0.26 & 1.00 & & & \\
\hline $\operatorname{Vol}\left(\mathrm{m}^{3}\right)$ & 0.73 & 0.66 & 0.29 & 1.00 & & \\
\hline Ln Ba & 0.23 & 0.28 & 0.97 & 0.33 & 1.00 & \\
\hline Ln Vol & 0.76 & 0.65 & 0.31 & 0.97 & 0.34 & 1.00 \\
\hline
\end{tabular}

\section{DISCUSSION}

In this study, the floristic diversity was found to be very similar to other tropical forests. Though there is little variation, in both the forests, species richness ( $63 \& 43$ species ha${ }^{1}$ respectively) and species diversity (4.12 \& 3.7 respectively) were observed as higher which is in accordance with some other Indian forests such as tropical forests of Shervarayan hills (Kadavul \& Parthasarathy 1999), Nelliampathy (Chandrasehkara \& Ramakrishnan 1994), Mylodai forest of Courtallum (Parthasarathy \& Karthikeyan 1997b). The higher number of species richness in the study area is attributed due to the presence of the riverine forest that contributes to the growth of many species. Species richness might be varied from forest to forest due to climatic factors, edaphic variability and anthropogenic activities and natural calamities. The number of species in NDWS is found less as compared to PRF which might be due to the factors such as over exploitation, wood smuggling, erosion, human encroachment, jhum cultivation as well as conversion of forest land into agricultural land etc. Whereas, the species richness value of PRF (63) indicates it as a mature tropical forest (Losose \& Leigh 2004). The higher value of species richness in PRF might be due to the presence of less anthropogenic activity, lack of jhum cultivation and every year flash flood. Every year flash flood helps the forest from non-conversion into agricultural field.

In the present study, the tree density for both the forests (PRF and NDWS) were analysed and found as 138.83-205.66 trees ha' ${ }^{-1}$ respectively which is less than the reports of other study (245-1800 trees ha-1) for several Indian tropical forests (Campbell et al. 1992; Visalakshi 1995; Ayyappan \& Parthasarathy 1999). The tree density might be lees owing to natural calamities, anthropogenic activities and soil properties. Conversely, earlier study supports the present findings regarding number of tree families and number of trees (Lu et. al. 2010).

The most obvious variation in tree species and the proportion of dominant species in the two forests can directly be attributed to rainfall distribution. PRF with more rainfall is predominantly an evergreen forest which situated in the hilly regions along its northern boundary. The basal area of the two forests ranged between 19.69 and $46.62 \mathrm{~m}^{2} \mathrm{ha}^{-1}$ (Table 2). The values are in range between $3.73-59.33 \mathrm{~m}^{2} \mathrm{ha}^{-1}$ for North East (IIRS 2002). Basal area of PRF is greater than $25.5 \mathrm{~m}^{2} \mathrm{ha}^{-1}$ in Rio Xingu, Brazil (Campbell et al. 1992) and $27.4 \mathrm{~m}^{2}$ ha${ }^{1}$ in Ecuador, Amazon (Valencia et al. 1994), but lower than $82.67 \mathrm{~m}^{2}$ ha $^{-1}$ of Reunion island 
(Strasberg 1996), 55-94 $\mathrm{m}^{2} \mathrm{ha}^{-1}$ of Kalakad in Western Ghats (Ganesh et al. 1996) and 62.49-90.29 $\mathrm{m}^{2} \mathrm{ha}^{-1}$ of Kholahat reserve forest and Gibbon Wildlife Sanctuary of Assam (Borah et al. 2015). The basal area value of NDWS is closer to the values (18.9-19.58 $\mathrm{m}^{2}$ $\mathrm{ha}^{-1}$ ) reported by Jha and Singh (1990) for dry tropical forest of Vindhyan region of India. The lower basal area in the forests likely results from smaller numbers of larger individuals (Gonzalez \& Zak 1996).

Importance value index (IVI) was found to range from 3.51- 8.35 and 4.79 -12.04 for both PRF and NDWS respectively (Tables $2 \& 3$ ). The IVI revealed that these two forests are dominated by relatively few species. The small values of IVI denote that these sites are under heavy disturbances.

The value of Shannon-Wiener index (H') for PRF and NDWS ranged between 4.12 and 3.7 respectively (Table 5). The larger the value of H', the greater the species diversity and vice versa (Parthasarathy \& Karthikeyam 1997a). An ecosystem with H'value greater than 2 has been regarded as medium to high diverse in terms of species (Barbour et al. 1999). Higher H' value for PRF indicates the most complexity whereas lower value of $H$ ' for NDWS depicts simplest community in term of species composition and diversity. According to some other study the diversity index is generally higher in tropical forests [5.06 and 5.40 for young and old stand respectively (Knight (1975)], whereas for Indian forests it ranged between 0.83 to 4.1 (Parthasarathy et al. 1992; Singh et al., 1984; Visalakshi 1995; Agni et al. 2000) which supports the present findings. The concentration of dominance (CD) of the present study sites ranged from 0.243 to 0.312 (Table 5). According to Whittaker and Niering (1975); Risser and Rice (1971); Singhal et al. (1986) and Pande et al. (1996), the value of concentration of dominance (CD) for temperate forests falls within the range of 0.10 to 0.99, however, for tropical forests the average value is 0.06 as reported by Knight (1975). The range of CD reported for tropical forest of India varies from 0.21 to 0.92 (Parthasarthy et al. 1992; Visalakshi 1995). The CD value reported in present study corresponds well with the reported range for tropical forest by several workers (Parthasarthy et al. 1992; Visalakshi 1995). The value of diversity index of the present study, therefore, lies within the range reported for tropical forests.

Tree stem volume at stand level is one of the most important parameters in forest management but its acquisition is very time consuming and expensive as it is normally obtained from field surveys (Tonolli et al. 2011). The estimated tree stem volume in this study is ranged from 53.92 to $130.15 \mathrm{~m}^{3} \mathrm{ha}^{-1}$ which is less than $391 \mathrm{~m}^{3} \mathrm{ha}^{-1}$ reported by Wittmann et al. (2008) and the $406-416 \mathrm{~m}^{3} \mathrm{ha}^{-1}$ reported by Tonolli et al. (2011) for multilayer forest areas in Italian Alps. The difference in this value might be due to the different methods adopted for volume computation. In this present study, an analytical formula, namely the Newton's volume estimation formula as suggested by Husch et al. (2003) was used. The variation in these values could also be attributed to factors like the sampling intensity, interlocation variations, soil properties and different climatic conditions.

Floristic diversity of forests plays an important role in storing carbon as the old growth and matured forest with big and diverse tree species contain more AGB and AGBC (Brown \& Lugo 1982; Terakunpisut et al. 2007; Borah et al. 2015). The AGB of the present study ranged from $91.04 \mathrm{Mg} \mathrm{ha}^{-1}$ (NDWS) to $110.07 \mathrm{Mg} \mathrm{ha}^{-1}$ (PRF) which is less than the study made on Tropical forest of Thailand (275 $\mathrm{Mg} \mathrm{ha}^{-1}$, Terakunpisut et al. 2007); South Africa (358.1 Mg ha-1, Mensah et al. 2016); Singapore (334.98- 209.04 $\mathrm{Mg} \mathrm{ha}^{-1}$, Ngo et al. 2013); Asia (225 Mg ha-1, Brown et al. 1991) and some studies made in India (307 $\mathrm{Mg} \mathrm{ha}^{-1}$, Ramachandran et al. 2007) while being comparable with the findings of Borah et al. (2013) (32.47 to 261.64 Mg ha-1); Haripriya (2000) (14 to $210 \mathrm{Mg} \mathrm{ha}^{-1}$ ); and Larson (2002) (50-430 
$\left.\mathrm{Mg} \mathrm{ha}^{-1}\right)$. Similarly, the values of AGBC stocks in this study ranged from $45.52 \mathrm{Mg} \mathrm{ha}^{-1}$ (NDWS) to $55.03 \mathrm{Mg} \mathrm{ha}^{-1}$ (PRF) which supports the other previous studies (Cairns et al. 2003; Sierra et al. 2007; Chaturvedi et al. 2011; Borah et al. 2013; Haripriya 2000; Larson 2002). Overall, compared to the PRF, the AGB and AGBC stocks were recorded less in NDWS.

\section{CONCLUSION}

In PRF, the forest area was moist mixed semi-evergreen forest, moist mixed deciduous forest, degraded forest, tall grasses and small grasses while in NDWS forest area was covered with Tropical Semi-evergreen rainforest with of evergreen and marsh forest. The species diversity and abundance compared are similar with other forest ecosystems. A total of 63 and 43 different tree species belong to 27 and 21 families was recorded in the PRF and NDWS, respectively. Compared to the PRF, a significantly less density of trees was recorded in the NDWS. Basal area also showed similar trend. Considerably higher AGB (110.07 Mg ha ${ }^{-1}$ ) and AGBC (55.03 $\mathrm{Mg} \mathrm{C} \mathrm{ha}^{-1}$ ) was recorded in the PRF compared to the NDWS. The highest correlation coefficient was obtained between the height and volume. A very weak correlation was observed between DBH and most of the other growth variables. From the findings it could be concluded that the higher AGB and AGBC in the PRF were due to diverse tree species while in the NDWS all the three parameters were lower due to reduced forest area as the Sanctuary faces large-scale encroachments by human populations (Sarma et al. 2008). Also in recent years, developmental activities such as establishment of the Numaligarh Refinery and increasing tea estates have influenced the species diversity.

\section{Acknowledgements}

The authors are thankful to Dr. D. Ramaiah, Director, CSIR-NEIST for his support and DST, Govt. of India for providing financial support.

\section{LITERATURE CITED}

Agni, T.; Pandit, A.; Pant, K. \& Tewari, A. 2000. Analysis of tree vegetation in the TaraiBhabhar tract of Kumaun Central Himalaya. Indian J. For. 23: 252 - 261.

Ayyappan, N. \& Parthasarathy, N. 1999. Biodiversity inventory of trees in a large scale permanent plot of tropical evergreen forest at Varagaliar. Anamalais, Western Ghats, India. Biodiv. Cons. 81: $1513-1551$.

Balakrishnan, N.P. 1983. Flora of Jowai. Vols. 1 \& 2, Botanical Survey of India, Kolkata.

Barbour, M.G.; Burk, J.H. \& Pitts, W.D. 1999. Terrestrial plant ecology. 3rd edn., Benjamin/ Cummings.

Borah, M.; Das, D.; Kalita, J.; Deka Boruah, H.P.; Phukan, B. \& Neog, B. 2015. Tree species composition, biomass and carbon stocks in two tropical forest of Assam. Biomass \& Bioen. 78: 25 - 35 .

Borah, N.; Nath, A.J. \& Das, A.K. 2013. Aboveground biomass and carbon stocks of tree species in tropical forests of Cachar District, Assam, northeast India. Intn. J. Ecol. Env. Sci. 39(2): 97 - 106.

Barooah, C. \& Ahmed, I. 2014. Plant diversity of Assam. A checklist of Angiosperms and Gymnosperms. ASTEC, Department of Science and Technology, Government of Assam, Guwahati. 
Boruah, P.; Phukan, U. \& Deka, P.P. 2003. Remote Sensing Application in Vegetation Mapping. In P.P. Baruah (ed.), Biodiversity of Eastern Himalayas Protected Areas. Handique Girl's College, Guwahati. Pp. 232 - 244.

Brown, S. \& Lugo, A.E. 1982. The storage and production of organic matter in tropical forests and their role in global carbon cycle. Biotropica 14: $161-187$.

Brown, S.; Gillespie, A.J.R. \& Lugo, A.E. 1991. Biomass of tropical forests of south and southeast Asia. Canad. J.f For. Res. 21: $111-117$.

Cairns, M.A.; Olmsted, I.J. Granados \& Argaez, J. 2003. Composition and aboveground tree biomass of a dry semi-evergreen forest on Mexico's Yucatan Peninsula. For. Ecol. Manag. 186: 125 - 132.

Campbell, D.G.; Stone, J.L. \& Rosas, A.Jr. 1992. A comparison of the phytosociology and dynamics of three floodplain (Varzea) forest of known ages, Rio Jurua, western Brazilian Amazon. Bot. J. Linn. Soc. 108: 231 - 237.

Chandrasehkara, U.M. \& Ramakrishnan, P.S. 1994. Vegetation and gap dynamics of a tropical wet evergreen forest in the Western Ghats of Kerala. Indian J. Trop. Ecol. 10: $337-354$.

Chaturvedi, R.K.; Gopalakrishnan, R.; Jayaraman, M.; Bala, G.; Joshi, N.V.; Sukumar, R. \& Ravindranath, N.H. 2011. Impact of climate change on Indian forests: a dynamic vegetation modeling approach. Mitigation and Adaptation Strategies for Global Change 16: $119-142$.

Chave, J.; Andalo, C.; Brown, S.; Cairns, M. A.; Chambers, J. Q.; Eamus, D.; Folster, H.; Fromad, F.; Higuchi, N.; Kira, T.; Lescure, J.P.; Nelson, B.W.; Ogawa, H.; Puig, H.; Riera, B. \& Yamakura, T. 2005. Tree allometry and improved estimation of carbon stocks and balance in tropical forests. Oecologia 145: $87-89$.

Chave, J.; Coomes, D.; Jansen, S.; Lewis, S.L.; Swenson, N. G. \& Zanne, A.E. 2009. Towards a worldwide wood economics spectrum. Ecol. Lett. 12: $351-366$.

Condit, R.; Sukumar, R.; Hubbell, S.P. \& Foster, R.B. 1998. Predicting population trends from size distributions: a direct test in a tropical tree community. Amer. Natur. 152: $495-509$.

Curtis, J.T. \& McIntosh Curtis, R.P. 1951. An Upland Forest Continuum in the PrairieForest Border Region of Wisconsin. Ecology 32(3): 476 - 496.

Dadhwal, V.K.; Singh, S. \& Patil, P. 2009. Assessment of phytomass carbon pools in forest ecosystems in India. Nat. Natur. Resour. Manag. Sys. Bull. 33: 41 - 57.

Fisher, R.A.; Corbet, A.S. \& Williams, C.B. 1943. The relation between the number of species and the number of individuals in a random sample of an animal population. $J$. Anim. Ecol. 12: 42 - 58.

Ganesh, T.; Ganesan, R.; Devy, M. S.; Davidar, P.; \& Bawa, K.S. 1996. Assessment of plant biodiversity at a mid-elevation evergreen forest of Kalakad-Mundanthurai Tiger Reserve, Western Ghats, India. Curr. Sci. 71: 379 - 392.

Gibbs, H.K.; Brown, S.; Niles, J.O. \& Foley, J.A. 2007. Monitoring and estimating tropical forest carbon stocks: Making REDD a reality. Env. Res. Lett. 2: $1-13$.

Gonzalez, O.J. \& Zak, D.R. 1996. Composition and structure of topical dry forest of St. Lucia, West Indies: the influence of edaphic properties and disturbance. Biotropica 28: 618-626. 
Goswami, T.K. \& Barua, K.N. 1996. Distributional notes on some plants in Assam. J. Econ. Taxon. Bot.. 20(3): $655-660$.

Haripriya, G.S. 2000. Estimates of biomass in Indian forests. Biomass \& Bioen. 19: $245-$ 258.

http://www.efloras.org

http://www.theplantlist.org/

Husch, B.; Beers, T.W. \& Kershaw, J.A. 2003. Forest Mensuration. $4^{\text {th }}$ edn., John Wiley \& Sons Inc., New Jersey, USA.

IIRS. 2002. Biodiversity Characterization at Landscape Level in North East, India Using Satellite Remote Sensing and GIS. Indian Institute of Remote Sensing, National Remote Sensing Agency, Department of Space, Dehradun.

Jha, C.S. \& Singh, J.S. 1990. Composition and dynamics of dry tropical forest in relation to soil texture. J. Veget. Sci. 1: $609-614$.

Kaduvul, K. \& Parthasarathy, N. 1999. Plant biodiversity and conservation of tropical semievergreen forest in the Shervarayan hills of Eastern Ghats, India. Biodiv. Cons. 8: 421 “ 439.

Kanjilal, U. N.; Kanjilal, P. C.; Das, A. \& De, R.N. 1934 - 1940. Flora of Assam. Vols. I IV, Govt. of Assam, Shillong.

Ketterings, Q.M.; Coe, R.; van Noordwijk, M.; Ambagau, Y. \& Palm, C.A. 2001. Reducing uncertainty in the use of allometric biomass equations for predicting aboveground tree biomass in mixed secondary forests. For. Ecol. Manag. 146: 199 - 209.

Knight, D.H. 1975. A Phytosociological analysis of species rich tropical forest on Barro Colorado Island: Panama. Ecol. Monogr. 45: 259 - 289.

Kunneke, A.; van Aardt Roberts, J.W. \& Seifert, T. 2014. Localisation of biomass potentials. In Bioenergy from Wood; Seifert, T., Ed.; Springer Netherlands: Dordrecht, The Netherlands, Pp. $11-41$.

Larson, A. 2002. Natural resources and decentralization in Nicaragua: Are local governments up to the job? World Development 31(1): $17-31$.

Losose, C. \& Leigh, G. 2004. Tropical Forest Diversity and Dynamism: Findings from a Large-Scale Plot Network. Chicago University Press, Chicago.

Lu, X. T.; Yin, J. X. \& Tang, J. W. 2010. Structure, tree species diversity and composition of tropical seasonal rainforests in Xishuangbanna, South-west China. J. Trop. For. Sci. 22(3): $260-270$.

Magalhães, T.M. \& Seifert, T. 2015. Estimation of tree biomass, carbon stocks, and error propagation in Mecrusse Woodlands. Open J. For. 5: $471-488$.

Mensah, S.; Veldtman, R.; Toit, B.; Kakaï, R.G. \& Seifert, T. 2016. Aboveground Biomass and Carbon in a South African Mistbelt Forest and the Relationships with Tree Species Diversity and Forest Structures Forests 7: 79.

Misra, R. 1968. Ecology Work Book. Oxford and IBH Publishing Company, Calcutta.

Ngo, K.M.; Turner, B.L.; Muller-Landau, H.C.; Davies, S.J.; Larjavaara, M.; Hassan, N.F.B.N. \& Lum, S. 2013. Carbon stocks in primary and secondary tropical forests in Singapore. For. Ecol. Manag. 296: 81 - 89. 
Pande, P.K.; Negi, J.D.S. \& Sharma, S.C. 1996. Plant species diversity and vegetation analysis in moist temperate Himalayan forests. Abstracted in First Indian Ecological Congress, New Delhi. [December 1996]. Pp. 27 - 31

Parthasarathy, N. \& Karthikeyam, R. 1997a. Plant biodiversity inventory and conservation of two tropical dry evergreen forests on coromandal coast, South India. Biodiv. Cons. 6: $1063-1083$.

Parathasarathy, N. \& Karthikeyan, R. 1997b. Biodiversity and population density of woody species in a tropical evergreen forest in Courtallum reserve forest, Western Ghats, India. Trop. Ecol. 38: 297 - 306.

Parthasarathy, N.; Kinhal, V. \& Praveenkumar, L. 1992. Plant species diversity and human impacts in the tropical wet evergreen forests of southern Western Ghats. In: IndoFrench Workshop on Tropical Forest Ecosystems: Natural Functioning and Anthropogenic Impacts. 26-27 November, French Institute, Pondicherry.

Picard, N.; Rutishauser, E.; Ploton, P.; Ngomanda, A. \& Henry, M. 2015. Should tree biomass allometry be restricted to power models? For. Ecol. Manag. 353: 156 - 163.

Pielou, E.C. 1966. The measurement of diversity in different types of biological collections. J. Theor. Biol. 13: $131-144$.

Ramachandran, A.; Jayakumar, S.; Haroon, R.M.; Bhaskaran, A. \& Arockiasamy, D.I. 2007. Carbon sequestration: estimation of carbon stock in natural forests using geospatial technology in the Eastern Ghats of Tamil Nadu, India. Curr. Sci. 92(3): 323 - 331.

Ravindranath, N.H.; Somashekhar, B.S. \& Gadgil, M. 1997. Carbon flow in Indian forests. Climate Change 35: 297 - 320.

Ravindranath, N.H. \& Ostwald, M. 2008. Approaches to estimate carbon stock changes. In: Advances in Global Change Research, Carbon Inventory Methods. Springer Publications.

Risser, P.G. \& Rice, E.L. 1971. Diversity in Tree Species in Oklahoma Upland Forests. Ecology 52: $876-880$.

Sarma, P.K.; Talukdar, B.K.; Baruah, J.K.; Lahkar, B.P. \& Hazarika, N. 2008. A GeoSpatial Assessment of Habitat Loss of Asian Elephants in Golaghat District of Assam. Gajah 28: 25 - 30.

Sasaki, N. \& Kim, S. 2009. Biomass carbon sinks in Japanese forests: 1966-2012. Forestry $82(1): 113-123$.

Seifert, T. \& Seifert, S. 2014. Modelling and simulation of tree biomass. In Bioenergy from Wood; Seifert, T., Ed.; Springer Netherlands: Dordrecht, The Netherlands, pp. 43 65.

Shannon, C.E. \& Weaver, W. 1963. The Mathematical Theory of Communication. University of Illinois Press, Urbana.

Sierra, C.A.; Del Valle, J.I.S.; Orrego, A.; Moreno, F.H.; Harmon, M.E.; Zapata, M.; Colorado, G.J.; Herrera, M.; Lara, W.; Restrepo, D.E.; Berrouet, L.M.; Loaiza, L.M. \& Benjumea, J. F. 2007. Total carbon stocks in a tropical forest landscape of Porce region, Colombia. For. Ecol. Manag. 2-3: 299 - 309.

Simpson, E.M. 1949. Measurement of diversity. Nature 163: 688.

Singh, S.P. 1998. Chronic disturbance, a principal cause of environmental degradation in developing countries. Env. Cons. 25(01): 1 - 2 . 
Singh, J.S. \& Singh, S.P. 1984. An Integrated Ecological Study of Eastern Kumaun Himalaya with Emphasis on Natural Resources. Vol. 1-3, Final Report (HCS/DST/ 187/76). Kumaun University, Nainital.

Singhal, R.M.; Rawat, V.R.S.; Kumar, P.; Sharma, S.D. \& Singh, H.B. 1986. Vegetation Analysis of Woody Species of Some Forest of Chakarta Himalaya, India", Indian For. 112: $819-823$.

Strasberg, D. 1996. Diversity, size composition and spatial aggregation among trees on a 1 ha rain forest plot at La Reunion. Biod. Cons. 5: 825-840.

Terakunpisut, J.; Gajaseni, N. \& Ruankawe, N. 2007. Carbon sequestration potential in aboveground biomass of Thong phaphun national forest, Thailand. Appl. Ecol. Env. Res. 5: $93-102$.

Tonelli, S.; Dalponte, M.; Neteler, M.; Rodeghiero, M.; Vescovo, L. \& Gianelle, D. 2011. Fusion of airborne LiDAR and satellite multispectral data for the estimation of timber volume in the Southern Alps, Rem. Sens. Env. 115(10): 2486 - 2498.

Valencia, R.; Balslev, H. \& Pazy-Miño, G. 1994. High tree alpha-diversity in Amazonian Ecuador. Biodiv. Cons. 3: $21-28$.

Visalakshi, N. 1995. Vegetation analysis of two tropical dry evergreen forests in southern India. Trop. Ecol. 36: 117 - 142.

Whittaker, R.H. 1972. Evolution and measurement of species diversity. Taxon 21:213 - 251.

Whittaker, R. H. \& Niering, W.A. 1975. Vegetation of the Santa Catalina Mountains, Arizona. V. Biomass, Production, and Diversity along the Elevation Gradient. Ecology 56(4): $771-790$.

Wittmann, F.; Zorzi, B.T.; Tizianel, F.A.T.; Urquiza, M.V.S.; Faria, R.R.; e Sousa, N.M.; Módena, É. de S.; Gamarra, R.M. \& Rosa, A.L.M. 2008. Tree Species Composition, Structure, and Aboveground Wood Biomass of a Riparian Forest of the Lower Miranda River, Southern Pantanal, Brazil. Folia Geobot. 43: 397 - 411. 